\title{
Geoffrey of Monmouth and the Conventions of History Writing in Early 12th-Century England
}

\author{
Georgia Henley
}

Modern critics of Insular 12th-century history have tended to view Geoffrey of Monmouth's historiographical project in terms of its differences from the other Latin works of Insular history of his time (particularly William of Malmesbury, Henry of Huntingdon, Orderic Vitalis, and John of Worcester), reading him as an outlier departing from the conventions of his contemporaries by penning something previously unknown, outside the historical mode, and likely spurious. Yet when viewed in tandem, the works of Geoffrey and his contemporaries are in fact united by key similarities in form, structure, classical allusion, and scope, even as they are separated by treatment of sources, content and focus, and reception. In this chapter, I situate Geoffrey's De gestis Britonum in the context of the longform histories of his contemporaries, particularly William of Malmesbury's Deeds of the English Kings (Gesta regum Anglorum) and Henry of Huntingdon's History of the English (Historia Anglorum), establishing their shared adherence to the conventions of history writing and its attendant rhetorical strategies, and noting where Geoffrey departs - perhaps subversively from such conventions. Though Caradog of Llancarfan seems to have been an important contemporary of Geoffrey as well, given that Geoffrey mentions him by name, I do not compare Geoffrey's work to Caradog's saints' lives, focusing instead on longform narrative history; nor do I discuss other contemporaries due to constraints of space. Following an assessment of the conventions of the genre and how they are satisfied by each of the three authors, I examine the three works according to the unifying theme of conquest, demonstrating that Geoffrey's departure from his contemporaries lies primarily in his treatment of sources and his focus on the Britons, not on the flagrant departure from history conventions as is sometimes claimed. These key differences have nevertheless resulted in a vastly different reception history for his work, including modern critical reception, compared to William and Henry. I conclude by offering an interpretation of Geoffrey's motives for writing in light of this comparison. 
I begin by considering the ways in which the three works are united by purpose and history conventions. The three historians were working in the second generation after the Norman Conquest of England: the earliest version of William's Deeds of the English Kings was written by $c .1125$, Geoffrey's $D G B$ was in circulation before January 1139, and Henry's History of the English circulated by $c .1130$ with a series of expanded versions issued until $c .1154 .{ }^{1}$ They are dedicated to patrons within the same milieu, including Alexander, bishop of Lincoln, and Robert, earl of Gloucester, indicating similar audiences and aspirations for the three works. ${ }^{2}$ The works were also considered together by contemporary readers: the $D G B$ is paired with William's Deeds of the English Kings in six

1 I am grateful to Joshua Byron Smith, Thomas O'Donnell, and anonymous reviewers for comments on this chapter. For background on William of Malmesbury, see D.H. Farmer, "William of Malmesbury's Life and Works", Journal of Ecclesiastical History 13 (1962), 39-54 and R.M. Thomson, William of Malmesbury, Woodbridge, 2003; for background on Henry of Huntingdon, see D. Greenway, "Henry (c. 1088-c. 1157), Historian and Poet", Oxford Dictionary of National Biography, <https://doi.org/10.1093/ref:odnb/12970> (accessed 18 May 2019); J. Gillingham, "Henry of Huntingdon and the Twelfth-Century Revival of the English Nation", in S. Forde, L. Johnson, and A. Murray (eds.), Concepts of National Identity in the Middle Ages, Leeds, 1995, pp. 75-101 (repr. in id. (ed.), The English in the Twelfth Century: Imperialism, National Identity and Political Values, Woodbridge, 20oo, pp. 123-44); and id., "Henry of Huntingdon in His Time (1135) and Place (between Lincoln and the Royal Court)", in K. Stopka (ed.), Gallus Anonymous and His Chronicle in the Context of Twelfth-Century Historiography from the Perspective of the Latest Research, Krakow, 2010, pp. 157-72.

2 Geoffrey dedicates the $D G B$ to Robert, earl of Gloucester, with some versions dedicating the work jointly to Robert and Waleran, count of Meulan. One manuscript (Bern, Burgerbibliothek, 568) contains a joint dedication to Robert, earl of Gloucester and King Stephen. The $P M$, which circulated independently prior to the issuing of the $D G B$, was reportedly commissioned by Alexander, bishop of Lincoln, and the $V M$ is addressed to Robert de Chesney, bishop of Lincoln. Henry of Huntingdon says the History of the English was commissioned by Alexander, bishop of Lincoln, the same bishop who requested the prophecies from Geoffrey; a later (5th) version is dedicated to Robert de Chesney, the next bishop of Lincoln; to whom Geoffrey's $V M$ is addressed. William dedicates version T of Deeds of the English Kings to Empress Matilda, whose mother commissioned it, and versions A, B, C, and $\mathrm{D}$ to Robert, earl of Gloucester, the same dedicatee as Geoffrey's $D G B$. (William also writes a letter to David, king of Scotland and brother of Queen Matilda, asking him to authorize the work and give it to Empress Matilda). These overlaps in dedicatees indicate that the three authors ran in the same literary circles. For discussion of these dedicatees, how dedication was a targeted attempt at wide distribution and career advancement, as well as the publishing history of the three works, see J. Tahkokallio, The Anglo-Norman Historical Canon: Publishing and Manuscript Culture (Cambridge Elements in Publishing and Book Culture), Cambridge, 2019, pp. 9-12, 18-31, 35-70. 
manuscripts, ${ }^{3}$ William's Contemporary History in four manuscripts, ${ }^{4}$ William's Deeds of the Bishops of the English in two manuscripts, ${ }^{5}$ Henry of Huntingdon's History of the English in five manuscripts, ${ }^{6}$ and Henry's description of Britain in four manuscripts. ${ }^{7}$ These groupings suggest common interest in Insular history on the part of medieval and early modern readership. Furthermore, Henry himself was interested in the content of the $D G B$ : after seeing a copy of the text at Le Bec in January 1139, he wrote a letter to one Warin the Breton describing the work. ${ }^{8}$ While Henry did not see fit to add it to his own history, perhaps because, as Wright argues, it did not accord with Bede (the Trojan narrative of History of the English $\$ 9$ is from Historia Brittonum), the letter indicates interest in the Britons that is borne out in Henry's representation of the aduentus Saxonum, discussed in further detail below. ${ }^{9}$

The works are united by similarities. All three authors recognize a need to draw together a range of authoritative sources for Insular history (particularly Bede, Gildas, and Historia Brittonum, though each uses additional sources) to

3 Cambridge, Trinity College, R.5.34; London, British Library, Royal 13 D. ii and Royal 13 D. v; Oxford, All Souls College, 35; Philadelphia, The Free Library, E.247; Valenciennes, Bibliothèque Municipale, 792; information from Crick, SC. BL Royal 13 D. ii, containing the $D G B$, William's Deeds of the English Kings and The Contemporary History, is particularly interesting because of its associations with Robert, earl of Gloucester, including the fact that it was at Margam Abbey, a foundation of Robert's, by the early 13th century. Tahkokallio, Anglo-Norman Historical Canon, pp. 25-26 argues that its exemplars may have been presentation copies given to Robert by the authors.

4 TCC R.5.34; BL Royal 13 D. ii and Royal 13 D. v; All Souls' College, 35.

5 TCC R.5.34, BL Royal 13 D. v.

6 Brussels, Bibliothèque royal, 8495-8505 (just Book 9); Cambridge, St John's College, G.16; Exeter, Cathedral Library, 3514; Rouen, Bibliothèque municipal, U.74 (1177); Ushaw, Ushaw College, 6 .

7 Cambridge, Gonville and Caius College, 103/55; Cambridge, University Library, Mm.5.29; Lincoln, Cathedral Library, 98; and BL Royal 13 D. v. Compare all of this to Orderic Vitalis's Ecclesiastical History, which travels with the $D G B$ in just one manuscript (Leiden, Universiteitsbibliotheek, B.P.L. 20). For further details, see Crick, $S C$.

8 Henry of Huntingdon, History of the English Letter to Warin, ed. and trans. D. Greenway, Henry, Archdeacon of Huntingdon: Historia Anglorum. The History of the English People, Oxford, 1996, pp. 558-83. For further discussion, see N. Wright, "The Place of Henry of Huntingdon's Epistola ad Warinum in the Text-History of Geoffrey of Monmouth's Historia regum Britanniae: a Preliminary Investigation", in G. Jondorf and D.N. Dumville (eds.), France and the British Isles in the Middle Ages and Renaissance: Essays by Members of Girton College, Cambridge, in Memory of Ruth Morgan, Woodbridge, 1991, pp. 71-113. For the manuscript Henry might have seen at Le Bec Abbey, see Jaakko Tahkokallio's chapter in this volume.

9 Tatlock, $L H B$, p. 49, suggests that Henry borrows the name Kaerperis for Porchester from Geoffrey. In turn, Geoffrey seems to have used Henry's History of the English as a source for information about Constantine, Coel, Helena, and Maximus, as well as for information about the four paved Roman roads (see Tatlock, $L H B$, pp. 34, 121, 281). 
produce a unified survey of the history of the island on a massive scale. While Geoffrey focuses on the history of the Britons from the end of the Trojan war to the passage of dominion over the island to the English, and William and Henry focus on the history of the English from their arrival in Britain down to their own time, all three works are inflected by the political events of the times in which they wrote, particularly the struggle for succession between Matilda and Stephen. This results in a keen focus throughout each of the histories on the peaceful transfer of power, dynastic continuity and stability, and the dangers of civil war. In other words, quotations of Lucan are at the tips of their pens. ${ }^{10}$ The dedications to secular rulers and power brokers of the day indicate that the intended audiences included secular readers rather than monastic/ scholarly readers alone (unlike some other chronicles written in that era). ${ }^{11}$ The structure is longform narrative rather than annalistic, with attention to moral lessons, particularly the virtues of good rulers and the counterexamples of bad ones, as well as courtly entertainment, miracles and marvels, and concordance with international events.

Rhetorical similarities in all the prologues indicate high levels of education and Latin literacy and an awareness of the commonplaces of history according to the norms of the time. All three identify silences in the historical record that they desire to fill, presenting their histories as participating in the recovery of valuable, lost information. For Geoffrey, this is a gap that would have seemed larger and more pressing to him after reading the histories by William of Malmesbury and Henry of Huntingdon, and he opens his history with this very problem:

I was surprised that, among the references to [the kings of Britain] in the fine works of Gildas and Bede, I had found nothing concerning the kings who lived here before Christ's Incarnation, and nothing about Arthur and the many others who succeeded after it, even though their deeds were worthy of eternal praise and are proclaimed by many people as if they had been entertainingly and memorably written down. ${ }^{12}$

10 For Geoffrey and civil war, see P. Dalton, “The Topical Concerns of Geoffrey of Monmouth's Historia Regum Britannie: History, Prophecy, Peacemaking, and English Identity in the Twelfth Century", Journey of British Studies 44:4 (2005), 688-712; for Henry, civil war, and Lucan, see C.A.M. Clarke, "Writing Civil War in Henry of Huntingdon's Historia Anglorum", Proceedings of the Battle Conference on Anglo Norman Studies 30 (2009), 31-48.

11 Though see Tahkokallio's chapter in this volume for the monastic reception of the $D G B$.

$12 D G B$, Prologus 1.2-7: "in mirum contuli quod infra mentionem quam de eis Gildas et Beda luculento tractatu fecerant nichil de regibus qui ante incarnationem Christi inhabitauerant, nichil etiam de Arturo ceterisque compluribus qui post incarnationem successerunt 
With this statement, Geoffrey sets up the timely discovery of Walter's ancient book in the British tongue that conveniently fills the observed gap. ${ }^{13}$ At the same time, he positions himself as the authoritative interlocutor of the book because he has already heard stories about Arthur from the many (presumably Brittonic-language-speaking) people who have them memorized, a medium inaccessible to his Anglo-Norman audience.

In the same vein, in his opening letter to Empress Matilda, William says that his work was prompted by her mother Queen Matilda's desire to know more about Aldhelm and her West Saxon predecessors, which he fulfilled first with a list of the English kings, and then, when the list provoked further interest, a fully fleshed-out narrative of the queen's royal predecessors. ${ }^{14}$ That the queen would not know her family's history and would need to consult an expert to uncover it for her places William in a position of historical authority which he modulates with appropriate humility. When William's grief over the queen's death causes him to put the work aside, he is persuaded by his friends, and by the importance of the work itself, to take it up again, "for it both seemed and was quite wrong that the memory of those great men should remain buried and their deeds die with them." 15 His history recuperates the deeds of the great English kings both in honor of their memory and for the benefit of their descendants, in this case, Empress Matilda and her half-brother Robert of Gloucester. Another of his motivations for writing is "to bring forcibly into the light things lost in the rubbish-heap of the past". 16

Henry of Huntingdon, though he does not write specifically of recovery and recuperating historical gaps as William and Geoffrey do, raises the stakes of history in his dedication to Bishop Alexander by presenting history as the line dividing men from brutes:

The knowledge of past events has further virtues, especially in that it distinguishes rational creatures from brutes, for brutes, whether men or

repperissem, cum et gesta eorum digna aeternitate laudis constarent et a multis populis quasi inscripta iocunde et memoriter praedicentur."

$13 D G B$, Prologus 2.10.

14 William of Malmesbury, Deeds of the English Kings Letter II, 5, ed. and trans. R.A.B. Mynors, completed by R.M. Thomson and M. Winterbottom, William of Malmesbury: Gesta Regum Anglorum, The History of the English Kings, 2 vols., Oxford, 1998-99, vol. 1, pp. 8-9.

15 William of Malmesbury, Deeds of the English Kings Letter II, 6, ed. and trans. Mynors, vol. 1, pp. 8-9: "quia uidebatur et erat indignum ut tantorum uirorum sepeliretur memoria, immorerentur gesta."

16 William of Malmesbury, Deeds of the English Kings Prologue to Book II, 2, ed. and trans. Mynors, vol. 1, pp. 150-51: "ut res absconditas, quae in strue uetustatis latebant, conuellerem in lucem". 
beasts, do not know - nor, indeed, do they wish to know - about their origins, their race and the events and happenings in their native land ... now we must pass over those whose life and death are to be consigned to perpetual silence. ${ }^{17}$

For Henry, awareness of the past, and even more importantly, learning lessons from past deeds, has a moral imperative, separating men from the mindless presentism that characterizes animals and "brutish" men. In doing so, he places the history of the English in the sacred history of salvation, elevating it above the narratives of the classical poets like Homer. While he cites Homer as precedent, his history - and the English people themselves - exceeds classical precedent by striving not for worldly glory and fame alone, but for eternal life. ${ }^{18}$

Throughout his first prologue, Henry emphasizes the didactic function of history, contextualizing the deeds of the English kings in the models of Homer and the Old Testament. ${ }^{19}$ He takes Homer as precedent for recording, better than the moral philosophers, the virtues of great men like Ulysses, Agamemnon, Nestor, and Menelaus, and the negative examples of Ajax, Priam, Achilles, and Paris; he also cites the Old Testament models of Abraham, Moses, Jacob, Joseph, Ahab, and others for moral instruction. ${ }^{20}$ Several times he professes the edifying, moral function of the genre in language like the following:

In the recorded deeds of all peoples and nations, which are the very judgements of God, clemency, generosity, honesty, caution and the like, and their opposites, not only provoke men of the spirit to what is good and deter them from evil, but even encourage worldly men to good deeds and reduce their wickedness ... In this work the attentive reader will find what to imitate and what to reject, and if, by God's help, he becomes a

17 Henry of Huntingdon, History of the English Prologue, ed. and trans. Greenway, pp. 4-5: "Habet quidem et preter hec illustres transactorum noticia dotes, quod ipsa maxime distinguat a brutis rationabiles. Bruti namque homines et animalia unde sint nesciunt, genus suum nesciunt, patrie sue casus et gesta nesciunt, immo nec scire uolunt."

18 For discussion of Henry of Huntingdon's focus on the theme of contemptus mundi, see N.F. Partner, Serious Entertainments: The Writing of History in Twelfth-Century England, Chicago and London, 1977, pp. 33-39.

19 For discussion of a shift away from didactic function in history writing of the late 12th century, see M. Staunton, "Did the Purpose of History Change in England in the Twelfth Century?" in L. Cleaver and A. Worm, Writing History in the Anglo-Norman World. Manuscripts, Makers, and Readers, c.1066-c.125o, Woodbridge, 2018, pp. 7-28.

Henry of Huntingdon, History of the English Prologue, ed. and trans. Greenway, pp. 2-5. 
better person for this emulation and avoidance, that will be for me the reward I most desire. ${ }^{21}$

His justification for writing History of the English articulates one of the essential functions of medieval history writing: to provide moral examples digna memoria, "worthy of memory", for readers to follow and to learn from, in the same way that they might benefit from reading hagiography or the Bible.

In his study of the conventions of medieval historiography, which did not see historical truth in the same way we see it in today, Ray cites Funkenstein who "has of late contended that in the Middle Ages the basic materials of history were not our facts but digna memoria, things made worthy of memory by their pertinence to a Christian conduct of life. A medieval 'fact' was therefore proper to moral experience and so had about it certain ideal associations", rather than the literal factual accuracy we anticipate from history today. ${ }^{22}$ This idea of history as a teacher precedes the medieval period, with roots in the writings of Cicero, Livy, and St Paul; it is also expressed by contemporaries John of Salisbury, Gervase of Canterbury, and Robert of Torigni. ${ }^{23}$

The didactic purpose of history is a function of medieval writers' conceptions of historical truth. Medieval writers of history took a providential view of history that is different from modern conventions. For medieval writers, the truth quality of history was not a matter of facts, as we would see them today, but of theology. ${ }^{24}$ Bede, for example, is not interested in causality or how human affairs might unfold naturally "by a standard of factual truth", but rather in how events occur according to God's power. ${ }^{25}$ In the providential view, God's judgement is not something we wait for but something that is carried out piecemeal, prefiguring the last judgement. ${ }^{26}$

21 Henry of Huntingdon, History of the English Prologue, ed. and trans. Greenway, pp. 4-5, 6-7: "Sic etiam in rebus gestis omnium gentium et nationum, que utique Dei iudicia sunt, benignitas, munificentia, probitas, cautela et his similia, et contraria, non solum spirituales ad bonum accendunt et a malo repellunt, sed etiam seculares ad bona sollicitant et in malis minuunt ... In quo scilicet opere sequenda et fugienda lector diligens dum inuenerit, ex eorum imitatione et euitatione Deo cooperante melioratus, michi fructum afferet exoptabilem."

R.D. Ray, "Medieval Historiography Through the Twelfth Century", Viator 5 (1974), 33-59, at p. 47; A. Funkenstein, Heilsplan und natürliche Entwicklung: Formen der Gegenartsbestimmung im Geschichtsdenken des hohen Mittelalters, Sammlung Dialog 5, Munich, 1965 .

23 Staunton, "Did the Purpose of History Change", pp. 10-11, 18.

24 Ray, "Medieval Historiography", p. 46.

25 Ray, "Medieval Historiography”, pp. 43-44.

26 Ray, "Medieval Historiography", p. 45. 
William of Malmesbury, too, sees his work as performing the didactic function, following the precedent set by authors in the "old days" (antiquitus):

It is true that in the old days books of this kind were written for kings or queens in order to provide them with a sort of pattern for their own lives, from which they could learn to follow some men's successes, while avoiding the misfortunes of others, to imitate the wisdom of some and to look down on the foolishness of others. ${ }^{27}$

This didactic value, William writes, is what motivates Matilda's interest in history and his interest in writing it. History, he writes, "adds flavor to moral instruction by imparting a pleasurable knowledge of past events". ${ }^{28}$ To William, history is an enjoyable way to absorb moral instruction. He follows through on this idea throughout his work, commenting on the moral virtues and vices of England's kings, overall promoting wisdom, learning, piety, pilgrimage to Rome, and lawfulness, and maligning bad decision-making, treachery, adultery, conspiracy, and tyranny. It is clear that he is urging his intended aristocratic audience to follow the good examples of English saints, like Æthelthryth, Edmund, and Cuthbert, and peaceful, just Christian kings like Æthelberht, Cenwulf, Oswald, Alfred, and Æthelstan over violent, cowardly kings who degrade learning like Ceolred, Osred, and Æthelred. By contrast, the moral imperative of history is not explicit in Geoffrey's prologue to the $D G B$, nor in the $V M$. The lessons of history are instead implicit, both in Geoffrey's character descriptions, which provide the occasional positive example for kings to follow, with particular emphasis on generosity, martial prowess, wisdom, and the building of civic works during peacetime. ${ }^{29}$

In contrast to William and Henry, who are building a precedent for peacetime stability and piety for their intended readers, Geoffrey offers far more negative examples of rulership than positive ones. The picture he paints of early Britain is one of constant treachery, power struggle, jealousy, and vindictiveness, resulting in constant instability and an overall downward arc of history. Unlike Henry and William, Geoffrey uses negative examples of morally

27 William of Malmesbury, Deeds of the English Kings Letter II, 4, ed. and trans. Mynors, vol. 1, pp. 6-7: "Solebant sane huiusmodi libri regibus siue reginis antiquitus scribi, ut quasi ad uitae suae exemplum eis instruerentur aliorum prosequi triumphos, aliorum uitare miserias, aliorum imitari sapientiam, aliorum contempnere stultitiam."

28 William of Malmesbury, Deeds of the English Kings Prologue to Book II, 1, ed. and trans. Mynors, vol. 1, pp. 150-51: "iocunda quadam gestorum notitia mores condiens, ad bona sequenda uel mala cauenda legentes exemplis irritat".

29 Brutus, for example, is generous, wise, and aggressive in battle ( $D G B$, i.7); Riuallo is peaceful and fortunate $(D G B$, ii.33). 
deficient, treacherous ruling families to argue for present-day stability and the assurance of peace afforded by dynastic continuity. This is still a providential view of history with didactic meaning. ${ }^{30}$

With the didactic function of history in mind, each of the three authors make the decision to attach morality to rightful rule over the island of Britain, bringing Insular history in line with sacred history. Taking inspiration from Gildas and from the punishments inflicted by God on the Israelites when they broke the commandments, they associate bad rulers with moral decline, especially with reference to the Britons. ${ }^{31}$ For Henry and William, the theme of divine punishment positions the Britons as a negative example that the English should be careful not to follow. For Geoffrey, the theme provides explanation for the Britons' decline and loss of their independent kingdom, and he describes the Britons' decline and consequent loss of the island of Britain in moral terms. Following a description of Gormundus and his Saxon allies pushing Kareticus into Wales and laying waste to the whole island, he addresses the readers in the language of lamentation:

Why, you slothful race, weighed down by your terrible sins, why with your continual thirst for civil war have you weakened yourself so much by internal strife? ... Your kingdom is divided against itself, lust for civil strife and a cloud of envy has blunted your mind, your pride has prevented you from obeying a single king, and so your country has been laid waste before your eyes by most wicked barbarians ... ${ }^{32}$

Here Geoffrey is at his most direct in blaming British vices for the triumph of the pagan Saxons, whose arrival occurs during the disastrous rule of the cunning and jealous Vortigern. ${ }^{33} \mathrm{~A}$ similar explanation is given later in the voice of Caduallo. Having fled into exile in Brittany, Caduallo, who knows his Gildas,

$30 \quad$ For further discussion of Geoffrey's participation in providential history, which goes against some critical views of him as a secular writer in the extreme, see Barry Lewis's contribution to this volume.

31 For discussion see Henry of Huntingdon, History of the English, ed. and trans. Greenway, p. lix; Lev. 26, Jer. 14, Isaiah 24; for Geoffrey's biblical quotations and allusions, see Paul Russell's chapter in this volume.

$32 \quad D G B$, xi.185.141-43, 147-50: "Quid, ociosa gens pondere inmanium scelerum oppressa, quid semper ciuilia proelia siciens tete domesticis in tantum debilitasti motibus ... Quia ergo regnum tuum in se diuisum fuit, quia furor ciuilis discordiae et liuoris fumus mentem tuam hebetauit, quia superbia tua uni regi oboedientiam ferre non permisit, cernis iccirco patriam tuam ab impiissimis paganis desolatam ..."

$33 D G B$, vi.98.248-50. In Geoffrey's version of events, Vortigern does not invite Hengist and Horsa to Britain to help defend its people; they arrive on their own, and Vortigern makes a deal with them. 
attributes the loss of his kingdom to his unworthy ancestors, who were proud, immoral, and filled with greed. The moral judgement is explicit:

As the historian Gildas bears witness, they harbored not just this sin, but all sins to which mankind is prey, and above all, those which suppress all virtue, namely hatred of truth and those who maintain it, love of lies and those who weave them, preference for evil in the place of good, respect for wickedness in the place of kindness ... ${ }^{34}$

For this reason, God has sent the Saxons to dispossess them of their land. A similar sentiment is expressed in the $V M$ in the voice of Merlin, uttering a prophecy to his sister, Ganieda, in King Rodarch's hall: "O the madness of the Britons! Their universal affluence leads them to excess. They are not satisfied with peace. A Fury goads them on. They engage in civil war and family feuds. They allow the churches of the Lord to go to ruin, and drive the holy bishops out into distant lands." ${ }^{35}$ Merlin predicts the successive conquests of the Saxons, Danes, and Normans. In this, Geoffrey provides an explanation for the Britons' loss of sovereignty, placing blame on the Britons themselves and implicitly informing his contemporary audience of aristocratic rulers of the dangers of straying off the moral path.

William and Henry, too, associate bad rulership with moral decay. William frequently promotes piety and learning and opposes bad behavior through the examples of England's early rulers. Eadbald, for example, begins his reign by reverting to paganism and sexually assaulting his stepmother, though later he repents, converts, and gives gifts to the monastery outside Canterbury, which is to be praised. ${ }^{36}$ There are many examples of this sort of royal conversion narrative in Deeds of the English Kings. Boniface's letter to Æthelbald, recorded by William, admonishes Æthelbald for abolishing the privileges of various monasteries and for the widespread sin of adultery, which will corrupt his race:

$34 D G B$, xi.195.355-59: "ut Gildas historicus testatur, non solum hoc uitium sed omnia quae humanae naturae accidere solent et praecipue, quod tocius boni euertit statum, odium ueritatis cum assertoribus suis amorque mendacii cum fabricatoribus suis, susceptio mali pro bono, ueneratio nequitiae pro benignitate ..."

$35 V M$, ll. 580-85: "O rabiem Britonum, quos copia diviciarum / usque superveniens ultra quam debeat effert! / Nolunt pace frui, stimulis agitantur Herenis. / Civiles acies cognataque prelia miscent. / Ecclesias Domini paciuntur habere ruinam pontificesque sacros ad regna remota repellunt."

36 William of Malmesbury, Deeds of the English Kings i.1o.2-4, ed. and trans. Mynors, vol. 1, pp. $30-31$. 
If the English nation does as we are accused of doing in France and Italy and by the very heathen themselves, and spurning lawful wedlock becomes rotten with adultery, there will arise from such mingled unions a coward race, despising God, whose corrupt behavior will be the ruin of their country ... ${ }^{37}$

Eventually, the Mercian line withers due to weakness. ${ }^{38}$ By implication, repeated sins and poor rulership corrupt the royal line and cause it to fail, both in body and in rule over England.

Like Geoffrey, a Gildasian view of history is present in William's narrative. Following the death of Bede, William laments the loss of letters and the increase of evil in the kingdom of Northumbria, quoting a letter from Alcuin to Æthelheard, archbishop of Canterbury:

It is written in the book of Gildas, wisest of the Britons, that it was through the avarice and rapine of their princes, through the iniquity and injustice of their judges, because their bishops would not preach and their people were wanton and corrupted, that those same Britons lost their country. Let us beware that the self-same vices do not re-establish themselves in our own day ... ${ }^{39}$

An explicit connection is made between vice and the right to rule a kingdom, determined by God and punishment. Peoples who have polluted their line with sin are not fit to rule. Vortigern is "unready and unwise, devoted to carnal pleasures and the servant of almost every vice", including incest. ${ }^{40}$ When William mentions descendants of the Britons in his day, it is in the language of

37 William of Malmesbury, Deeds of the English Kings i.8o.4, ed. and trans. Mynors, vol. 1, pp. 116-17: "quod si gens Anglorum, sicut in Frantia et Italia et ab ipsis paganis nobis improperatur, spretis legitimis matrimoniis per adulteria defluit, nascitura ex tali commixtione sit gens ignaua et Dei contemptrix, quae perditis moribus patriam pessumdet ..."

38 William of Malmesbury, Deeds of the English Kings i.96, ed. and trans. Mynors, vol. 1, pp. 140-41.

39 William of Malmesbury, Deeds of the English Kings i.70.4, ed. and trans. Mynors, vol. 1, pp. 104-05: "Legitur in libro Gildae, sapientissimi Britonum, quod idem Britones propter auaritiam et rapinam principum, propter iniquitatem et iniustitiam iudicum, propter desidiam predicationis episcoporum, propter luxuriam et malos mores populi patriam perdidere. Caueamus haec eadem uitia nostris temporibus inolescere ..."

40 William of Malmesbury, Deeds of the English Kings i.4.1, ed. and trans. Mynors, vol. 1, pp. 20-21: "nec manu promptus nec consilio bonus, immo ad illecebras carnis pronus omniumque fere uitiorum mancipium ..." 
corruption: Æthelstan sweeps the Western Britons, or Cornish, out of Exeter, ridding the city of a contamina gens, "infected race".41

Henry of Huntingdon, too, uses the Britons as a didactic lesson, warning his own noble readers against following in their path. At the conclusion to Book I, which sets out a Roman imperial past for early Britain, Henry writes that God sends prosperity to the Britons to test them. They respond to the time of plenty by falling into crime, cruelty, and wickedness. God punishes them with a plague, but this does not stop them, so he sends a worse punishment: invasions by Scots and Picts and, eventually, the Saxons. The link between the Britons' sin and punishment is explicit. ${ }^{42}$ At the beginning of Book II, on the coming of the English to Britain, Henry transforms the pagan wish for worldly glory and fame into a Christian trust in God:

We shall have true glory, fame, and honour if we rely, with cheerfulness and joy, on Him who is the only true one, if we put all our hope and trust in God, not in the sons of men, as did the Britons, who, deserting God and the grandeur of His fear, sought aid from pagans [i.e. Hengist and Horsa], and gained their just deserts. ${ }^{43}$

Their punishments, Henry writes, include the loss of glory on earth and the posthumous treatment of their deeds as amara, tedii scilicet et odii generatrix, "distasteful, a cause for loathing and disgust". ${ }^{44}$ All three authors thus attach moral virtue to rightful rule over the island of Britain, and use the Britons as a negative example for their contemporary readers. Sin and vice lead to the withering of the royal line, pollution and disgust, the loss of learning and letters, and the failure of whole kingdoms. The didactic function of history is a backdrop to all they depict.

41 William of Malmesbury, Deeds of the English Kings ii.134.6, ed. and trans. Mynors, vol. 1, pp. 216-17. For William, the Welsh descendants of the Britons are reduced to two general uses in his narrative: they turn up occasionally to demonstrate the antiquity and primacy of Glastonbury, and they are a foil to the victorious English kings, who often demonstrate emergent martial and imperial prowess by putting down Welsh rebellions.

42 Henry of Huntingdon, History of the English i.47, ed. and trans. Greenway, pp. 74-77.

43 Henry of Huntingdon, History of the English ii.1, ed. and trans. Greenway, pp. 78-79: "Veram autem gloriam et famam et honorem habebimus, si ei qui solus uerus est cum iocunditate et leticia innitamur, si spem nostram et fiduciam omnem in Deo ponamus, non in filiis hominum, sicut Britanni, qui Deo abiecto et magnificentia timoris eius auxilium pecierunt a paganis, habueruntque sed quale decebat." For discussion of this passage, see Henry of Huntingdon, History of the English, ed. and trans. Greenway, p. lxii, who notes its thematic debt to Psalms 57:8.

Henry of Huntingdon, History of the English ii.1, ed. and trans. Greenway, pp. 78-79. 
A number of additional conventions are shared by the three authors, including an episodic structure fit for short, digestible bits of reading (typically divided neatly by successions of kings); gestures toward writing in a "humble" style punctuated by moments of elevation that show off learning; and commonplace tools to portray characters' personalities, including direct discourse and physical description. ${ }^{45}$ Geoffrey, Henry, and William use direct discourse most often in battle preparation, in which kings rouse their men with inspired speeches, a commonplace in history writing probably modeled after Sallust. Other than pre-battle speeches and the $P M$ in the voice of Merlin, Geoffrey does not depart from the authorial voice he uses to narrate the $D G B$ throughout. By contrast, William and Henry include a number of written sources in their histories that disrupt their own authorial voices with the insertion of other authorities relevant to early English history, including letters by Alcuin, Gregory, and Boniface that they have gotten from Bede. William, for example, often includes grants from kings to various monasteries, with particular focus on Glastonbury in order to inscribe these royal gifts into perpetuity. These digressions add international scope, relevance, and legitimacy to William's narrative. In other words, Geoffrey's contemporaries include the voices of other authors in their histories. It is not in their interest to disguise written sources; rather, it adds to their authority.

It is through the elision of sources and the establishment of authority that Geoffrey departs the most from the commonplace tools of history writing exemplified by his two contemporaries. The entire $D G B$ is written in his voice, with no departure or digression from the main narrative other than the deliberately marked departure of the $P M$, and little discussion of sources. While this results in a cohesive narrative structure, it has not won Geoffrey any favors in the reception of his work, contemporary or modern. The $D G B$ is widely regarded as a work of imagination rather than history, and the lack of survival of Welsh written sources does not help. ${ }^{46}$

The establishment of authority by the historian through proper handling of evidence was particularly important "in a world of slow and often unverifiable communications". ${ }^{47}$ For this reason, historians typically spent some time proving the quality of their interpretive faculties by discussing education level, research methods, and ability to assess evidence carefully. ${ }^{48}$ William and

Ray, "Medieval Historiography", p. 56. Joshua Byron Smith reminds me that the redactor of the First Variant mostly rids the text of speeches.

46 For similar discussion, see Simon Meecham-Jones's contribution to this volume.

47 C. Given-Wilson, Chronicles: The Writing of History in Medieval England, London and New York, 2004, p. 6.

48 Given-Wilson, Chronicles, pp. 6-10. 
Henry follow these rules well, establishing their authority and claim to truth by discussing their sources explicitly, which they have painstakingly gathered and analyzed. Henry says, "I have followed the Venerable Bede's Ecclesiastical History where I could, selecting material also from other authors and borrowing from chronicles preserved in ancient libraries, and I have described past events down to the time of our own knowledge and observation", while William says he expands upon Bede and Eadmer with the addition of recent, eyewitness sources: "Whatsoever I have added out of recent history, I have either seen myself or heard from men who can be trusted."49 William, in particular, frequently mentions where he found his written sources, why he is including them, and whether they are truthful. Sometimes he risks potentially disreputable sources, asking his reader to judge for themselves; other times he vouches for their accuracy. As mentioned above, he includes letters, charters, and other documents in his text, which results in a sometimes digressive narrative that loops back to pick up dropped threads, but has the end result of establishing unimpeachable authority and trustworthiness. Henry refers to historians from whom he has gotten information and, following Bede, includes correspondence from the popes directing the conversion of the English. In both texts, written (and eyewitness) sources are undisguised, leaving the impression that they have not been tampered with.

Henry and William also do a good job of describing (some might say flaunting) their education. William, for example, communicates his authority by describing himself as a lifelong, learned reader, educated in the traditional disciplines:

I studied many kinds of literature, though in different degrees. To Logic, the armourer of speech, I no more than lent an ear. Physic, which cures the sick body, I went deeper into. As for Ethics, I explored parts in depth, revering its high status as a subject inherently accessible to the student and able to form good character; in particular I studied History, which adds flavour to moral instruction by imparting a pleasurable knowledge of past events, spurring the reader by the accumulation of examples to follow the good and shun the bad. ${ }^{50}$

49 Henry of Huntingdon, History of the English Prologue, ed. and trans. Greenway, pp. 6-7: "Bede uenerabilis ecclesiasticam qua potui secutus historiam, nonnulla etiam ex aliis excerpens auctoribus, inde cronica in antiquis reseruata librariis compilans, usque nostrum ad auditum et uisum preterita representaui"; William of Malmesbury, Deeds of the English Kings Prologue to Book I, 8, ed. and trans. Mynors, vol. 1, pp. 16-17: "Quicquid uero de recentioribus aetatibus apposui, uel ipse uidi uel a uiris fide dignis audiui." Mynors, vol. 1, pp. 150-51: "Et multis quidem litteris impendi operam, sed aliis aliam. 
The degree of agency he gives himself in this description of his educational credentials feeds directly into his self-fashioning as a skilled historian: curious, highly self-motivated, and dogged in gathering information. Henry, too, flashes his educational credentials at the very beginning of History of the English, quoting Horace in a proclamation that the best relief from suffering and affliction in the world comes from studying literature. ${ }^{51} \mathrm{He}$ follows this statement with a proliferation of classical and biblical references that reinforce this professed learned background.

Geoffrey, in contrast, has polished his sources to such a sheen as to be unrecognizable, and he does not spend time explicitly discussing his educational credentials. ${ }^{52}$ His knowledge of classical authors must be discerned by the equally-educated reader. He attributes his work to a book in the British tongue brought to him by Walter, archdeacon of Oxford, which he himself has translated into Latin. ${ }^{53}$ The authority of his work rests on these three details: it is ancient, it is in the British tongue, and Geoffrey has translated it faithfully. Geoffrey does not spend time in his prologue nor elsewhere establishing other kinds of credibility as a historian; he does not brag of his book learning, as Henry does, nor include letters and other documents. He does not perform his ability to gather and judge evidence. His departure from the conventions of historical writing in this way - which stands in particularly stark contrast to William and Henry's successful adherence to source study as establishing authority - perhaps explains the modern critical judgements about the success of the $D G B$ as credible history. William and Henry are available for modern historians' research; Geoffrey is not. ${ }^{54}$

This key difference has set Geoffrey on a fundamentally different reception trajectory than his contemporaries. Henry is remembered for his good judgement and rationality: for example, Elisabeth van Houts calls him a "pragmatic historian and an annalist" whose account of the Norman Conquest is "down to earth and rational".55 William, according to Antonia Gransden, is

Logicam enim, quae armat eloquium, solo libaui auditu; phisicam, quae medetur ualitudini corporum, aliquanto pressius concepi; iam uero ethicae partes medullitus rimatus, illius maiestati assurgo, quod per se studentibus pateat et animos ad bene uiuendum componat; historiam precipue, quae iocunda quadam gestorum notitia mores condiens, ad bona sequenda uel mala cauenda legentes exemplis irritat."

51 Henry of Huntingdon, History of the English Prologue, ed. and trans. Greenway, pp. 6-7; Horace, Carmina i.32.14, Epistles i.2.3-4.

$5^{2} \quad$ For Geoffrey's demonstrable use of Welsh, classical, and biblical sources, see chapters in this volume by Ben Guy and Paul Russell.

$53 \quad D G B$, Prologus 2.10.

54 Ray, "Medieval Historiography", p. 33.

55 E. van Houts, "Historical Writing", in C. Harper-Bill and E. van Houts (eds.), A Companion to the Anglo-Norman World, Woodbridge, 2003, pp. 103-22, at pp. 114, 113. 
"conscientious", "highly intelligent", showing "considerable critical acumen" and, happily, "circumspect about Arthurian legends and oral tradition". ${ }^{56} \mathrm{He}$ is commended by Rodney Thomson for "set[ting] an example of intelligent and imaginative judgement, of elegant expression and lucid planning, which are the hallmarks of the great historian". ${ }^{57}$ William's methods of research and his scrupulous attention to sources appeal to modern critics because they align so closely with our own expectations of historical accuracy. Sigbjørn Sønneysn writes, "it has been taken for granted that William in his capacity as a historian pursued the same ends as those pursued by modern-day historians." ${ }^{n 8}$ This reputation has probably also protected William's marvel stories and prophecies from the criticisms that Gerald of Wales and Geoffrey of Monmouth receive for the same sort of material. By contrast, C.N.L. Brooke declares that "there has scarcely, if ever, been a historian more mendacious than Geoffrey of Monmouth", while Alan Cobban labels him a "romance writer and historical poseur". ${ }^{59}$ Francis Ingledew calls the $D G B$ "a massive piece of fiction making", while Elisabeth van Houts styles it "bizarre", a "historical novel", a piece of "escapist historical writing". ${ }^{60}$ More criticisms of this sort could be furnished, but suffice it to say, critics take objection to how Geoffrey spurns the conventions of transparency of source material and treatment of evidence. ${ }^{61}$ And yet he shares many other conventions and features with his contemporaries - it is the use of evidence, inflected by the wide reception of the $D G B$ in the genre of romance, that fundamentally divides them. ${ }^{62}$

56 A. Gransden, Historical Writing in England, c.550-c.1307, London, 1974, pp. 168, 175.

57 R.M. Thomson, "William of Malmesbury: Life and Works", in id. in collaboration with M. Winterbottom, William of Malmesbury: Gesta Regum Anglorum, The History of the English Kings, Volume II. General Introduction and Commentary, Oxford, 1999, pp. xxxv-xlv.

$5^{8}$ S.O. Sønnesyn, William of Malmesbury and the Ethics of History, Woodbridge, 2012, p. 2.

59 A.B. Cobban, The Medieval English Universities: Oxford and Cambridge to c.15oo, Berkeley, 1988, p. 38; C.N.L. Brooke, "Geoffrey of Monmouth as a Historian", in C.N.L. Brooke, D. Luscombe, G. Martin, and D. Owen (eds.), Church and Government in the Middle Ages: Essays Presented to C.R. Cheney on his 7oth Birthday, Cambridge, 1976, pp. 77-91, at p. 78.

6o F. Ingledew, "The Book of Troy and the Genealogical Construction of History: The Case of Geoffrey of Monmouth's Historia regum Britanniae", Speculum 69:3 (1994), 665-704, at p. 670; van Houts, "Historical Writing", pp. 114, n. 59, pp. 114-15.

61 For discussion see J. Blacker, The Faces of Time: Portrayal of the Past in Old French and Latin Historical Narrative of the Anglo-Norman Regnum, Austin, 1994, pp. 1-52; Partner, Serious Entertainments, pp. 183-230; R. Ray, "Historiography", in F.A.C. Mantello and A.G. Rigg (eds.), Medieval Latin: An Introduction and Bibliographical Guide, Washington, 1996, pp. 639-49.

62 For Geoffrey as a writer of romance, see R.M. Stein, Reality Fictions: Romance, History, and Governmental Authority, 1025-1180, Notre Dame, 2006, pp. 108-20. 
In addition to the shared historical conventions (with the exception of treatment of sources) discussed above, the three large-scale surveys of the history of Britain share additional structural and thematic characteristics. Each is indebted to Bede's Ecclesiastical History, William and Henry quite closely, and Geoffrey less faithfully. ${ }^{63}$ Each uses an episodic structure, without annalistic dating, punctuated by the rise and fall of lines of kings, whether one line (in the case of Geoffrey), or five replaced by one (in the case of William and Henry). Their successes and failures are predicated upon a capricious mixture of Fortuna, God, and free will, each providing lessons to the intended aristocratic audience of royals and bishops. The histories are violent, bloody, and full of battles and treacherous acts, punctuated by moments of religious piety and peaceful governance, with cities settled and gifts made to churches. Each is substantively an origin legend, depicting the arrival of people by ship to the island of Britain and their conquest of the people who are already there. Conquest narratives from the perspective of the conqueror implicitly require justification of the act, and each author justifies the validity of conquest by explaining why the previous people deserved to lose control. This may be because they have sinned egregiously and are being punished by God, in the case of the Britons, or because they are monstrous, racialized giants without interest in governing nor indeed the ability to do so, in the case of Geoffrey's account of the arrival of Brutus and his people, or because they are weak, illadvised, and fail to produce heirs, in the case of the Norman Conquest of the English. In addition, each of the histories is interested in themes of conquest, divine punishment, sainthood, kingship, and national governance. The key difference in the texts is not form or structure, but content.

Having discussed how each of the works follow or subvert the conventions of their genre, the remainder of the chapter is interested in how each of the works treats the shared theme of conquest and the attendant treatment and portrayal of the Britons. Their interpretations of the aduentus Saxonum, which

63 For Geoffrey's reworking of Bede, see Rebecca Thomas's chapter in this volume and N. Wright, "Geoffrey of Monmouth and Bede", $A L 6$ (1986), 27-59. For William's debt to Bede, see E.J. Ward, "Verax historicus Beda:William of Malmesbury, Bede and Historia”, in R.M. Thomson, E. Dolmans, and E.A. Winkler (eds.), Discovering William of Malmesbury, Woodbridge, 2017, pp. 175-87; Sønnesyn, William of Malmesbury, pp. 125-27; for Henry's, see Henry of Huntingdon, History of the English, ed. and trans. Greenway, pp. lxxxvilxxxix; ead., "Authority, Convention and Observation in Henry of Huntingdon's Historia Anglorum", Anglo-Norman Studies 18 (1995), 105-21. 
is the main event shared by all three of the histories, shows the difference in perspectives of the authors.

William, writing first (in and before $c .1125$ ), dedicates the first several sections of his history $(\S \S 1-8)$ to a succinct narrative of the arrival of the Angles, Saxons, and Jutes, taken mostly from Bede. The brief image of the pre-Saxon past of Britain that he projects in $\S \S 1-2$ is one of discord and struggle. Britain is exposed to greatness under the Romans, with the great princes Severus and Constantine buried on the island. But, following Maximus's disastrous campaign in Gaul and the flight of all the good Britons to a colony on the western coast of Gaul, the island is left conterminarum gentium inhiationi ... obnoxia, "exposed to the greed of neighbouring peoples". ${ }^{64}$ Enter the Picts and Scots, who harry the remaining Britons even after they convince the Romans to help them build a defensive wall. The Britons beg for aid from King Vortigern, who invites the Angles and Saxons from Germany to help defeat the Scots. Vortigern, as discussed above, is depraved and ill-prepared for this alliance, focused instead on violating his own daughter and other sins. The arrival of the three Germanic peoples to the island is depicted positively from their point of view; their ships are spurred on by joy, prayers, and favorable winds; they are led by Hengist and Horsa of venerable lineage; they are received joyfully by the people of Britain. ${ }^{65}$ In short, they are depicted as saviors. The English quickly dispatch the Scots and settle the kingdoms of Kent and Northumbria in a marriage deal between Hengist's daughter and the lustful Vortigern. Concerning the transfer of power from the Britons to the English, William writes of the death of Vortigern's son, Vortimer: "with his decease the Britons' strength withered away, and their hopes dwindled and ebbed". ${ }^{66}$ A brief resurgence by Ambrosius "the sole surviving Roman" with the help of Arthur is dashed by the treachery of the long knives. ${ }^{67}$ Following the death of Hengist, William dives into an account of the succession of the kings of Northumbria: Eisc, Ohta, Eormenric, Æthelberht. He does not discuss the fate of the Britons; they disappear altogether from the narrative, cropping up only occasionally in the deeds of future English kings who must battle them at various points. The Roman and British past merely sets the stage for his careful, lengthy histories of each of the English kingdoms.

64 William of Malmesbury, Deeds of the English Kings i.2, ed. and trans. Mynors, vol. 1, pp. ${ }^{18-19 .}$

65 William of Malmesbury, Deeds of the English Kings i.5-6, ed. and trans. Mynors, vol. 1, pp. 22-23.

66 William of Malmesbury, Deeds of the English Kings i.8.2, ed. and trans. Mynors, vol. 1, pp. 26-27: "Sed eo extincto Britonum robur emarcuit, spes imminutae retro fluxere".

67 William of Malmesbury, Deeds of the English Kings i.8.2, ed. and trans. Mynors, vol. 1, pp. 26-27: "solus Romanorum superstes". 
While the English kings are certainly not always depicted in a positive light, the overall depiction William aims for is one of steadily increasing Christianity, learning, lawfulness, civic organization, and peace. For William, the conquest of Britain by the English is ordained and logical, a necessary blip before turning to the matter of the progressive development of the English kingdoms. ${ }^{68}$

By contrast, Henry's narrative of the aduentus Saxonum is much longer and much more interested in the Britons. He prefaces the event with a lengthy description of the island from Bede, a list of the cities of Britain and the Saxon shires of the current day, the island's weather, highways, and languages, and the Trojan origin of its founder, Bruto, taken from Historia Brittonum. In later versions of the history he includes a long succession of laudes for Roman emperors, taken from the Historia Romana. These men rule the Roman empire which, he takes pains to note, included Britain at that time. Britain's imperial Roman past is important to Henry, with particular interest in the emperor Constantine who marries Helena, daughter of Cole, the British king of Colchester. Following the aduentus Saxonum, which largely follows the William/Bede narrative outlined above with some minor variations, Hengist and his son Æesc violently expel the Britons and establish the kingdom of Kent.

Notably, unlike William, Henry does not exclude the Britons from his story of the rise of the English kingdoms. The death of Vortimer and the last battle with Ambrosius Aurelianus is not the final word on the subject. Hengist and his descendants fight dozens of bloody battles against Briton armies for several generations following their arrival $(\S \S 4-9)$, as do the rulers of Sussex (§§10-15), Wessex (§§16-18), Northumbria (§22), East Anglia (§25), and Mercia (§§27-29). The Britons in these battles are favorably portrayed, even if they lose. Fighting Hengist and Æsc, they are "splendidly arrayed" in twelve organized phalanges; in Ælle's siege of the city of Andredecester (Pevensey) they "swarm like bees" with "superior speed" and battle tactics; in a battle against Cerdic's nephews recently arrived from Germany the British leaders "drew up their battle lines against them most excellently according to the rules of warfare". 69 They are organized, disciplined, and frightening. In the battle with Cerdic's nephews, Stuf and Wihtgar, the gilded shields of the Britons are illuminated by the light of the sun, reflecting it off the hills as they approach

68 For William's history as a progression from barbarism to civilization, see J. Gillingham, "The Context and Purposes of Geoffrey of Monmouth's History of the Kings of Britain", Anglo-Norman Studies 13 (1990), 99-118 (repr. in id. (ed.), The English in the Twelfth Century, pp. 19-39, at pp. 28-29).

69 Henry of Huntingdon, History of the English ii.7, ed. and trans. Greenway, pp. 88-89: "nobiliter ordinatas", pp. 92-93: "quasi apes ... celeritate prestantiores"; pp. 96-97: "acies in eos secundum belli leges pulcherrime construxerunt." 
the Saxon army, terrifying them. Even if only to emphasize the significance of the English peoples' eventual dominance over the Britons, this editorializing of material taken from the Anglo-Saxon Chronicle links the Britons' battle strategies to their Roman imperial past, which Henry describes at length prior to the English arrival. Their fierceness in battle also recalls their pre-Roman ancestors who were able to hold off Julius Caesar for some time. ${ }^{70}$ Overall, for Henry, the suppression of the Britons is a piecemeal process, not assured, requiring immense planning, battle tactics, bravery, and perseverance over several generations of leaders and across a large geographical space. Eventually they win because of numbers, with more ships constantly arriving, and because God has rejected the Britons. ${ }^{71}$

Conquest is a thematic interest for each of the authors and each of them treat it slightly differently. Overall, Henry sees history as a series of successive conquests, plagues sent by God as punishment. The English conquest of Britain is one of many, with the Norman Conquest the most recent:

From the very beginning down to the present time, the divine vengeance has sent five plagues into Britain, punishing the faithful as well as unbelievers. The first was through the Romans, who overcame Britain but later withdrew. The second was through the Picts and Scots, who grievously beleaguered the land with battles but did not conquer it. The third was through the English, who overcame and occupy it. The fourth was through the Danes, who conquered it by warfare, but afterwards they perished. The fifth was through the Normans, who conquered it and have dominion over the English people at the present time. ${ }^{72}$

For Henry, the English conquest of Britain is paralleled by the more recent Norman Conquest, happening for the same reason (sent by God as punishment) and with the same results (a transfer of power to the new people). Incidentally, Henry does not see Brutus's arrival following a period of wandering from Italy, discussed several sections later, as one of the plagues. For Henry,

70 Henry of Huntingdon, History of the English i.12, ed. and trans. Greenway, pp. 31-33.

71 Henry of Huntingdon, History of the English ii.14, ii.18, ed. and trans. Greenway, pp. 96-97, $100-01$.

72 Henry of Huntingdon, History of the English i.4, ed. and trans. Greenway, pp. 14-15: "Quinque autem plagas ab exordio usque ad presens immisit diuina ultio Britannie, que non solum uisitat fideles, sed etiam diiudicat infideles. Primam per Romanos, qui Britanniam expugnauerunt sed postea recesserunt. Secundam per Pictos et Scotos, qui grauissime eam bellis uexauerunt, nec tamen optinuerunt. Terciam per Anglicos, qui eam debellauerunt et optinent. Quartam per Dacos, qui eam bellis optinuerunt, sed postea deperierunt. Quintam per Normannos, qui eam deuicerunt et Anglis inpresentiarum dominatur." 
the meaning that can be drawn from conquest is the theme of contemptus mundi, "contempt of the world": worldly power is temporary, and we should turn the eternal kingdom instead. ${ }^{73}$

Geoffrey's $D G B$, also interested in conquest throughout, is bookended by two conquests: first, Brutus's establishment of the kingdom of Britain following his ancestors' flight from Troy, a period of wandering, and the driving away of the giants who inhabited the island, and second, the arrival and rise of the Saxons, who take over from the Britons as divine punishment for their sins. In the middle of the $D G B$ is a protracted struggle against conquest by the Romans.

In Book I, the giants do nothing more than position Brutus and his friend Corineus as rightful conquerors of the island, for they had not occupied the land in a civilized manner. ${ }^{74}$ Brutus and his people gain ownership over the land more by divine right than by a series of violent battles. By contrast, Constantinus's conquest of Rome, and Arthur's conquest of much of Gaul, Scandinavia, and the islands neighboring Britain, plus his attempt to conquer Rome, position the Britons as an imperial power, in the same vein as Henry of Huntingdon. ${ }^{75}$ Hoelus, king of the Armoricans, addresses Arthur as follows: "for a third time one born of British blood will rule the Roman state. [The Sibyl's] prophecies have come true for two men already, since it is clear, as you said, that the noble princes Beli and Constantine have worn the crown of Rome." 76 The Roman associations of Britain's kings are necessary for understanding Geoffrey's depiction of the aduentus Saxonum. For Geoffrey, the story of Vortigern and Vortimer is simply a prelude to the extended story of

73 Henry of Huntingdon, History of the English ii.40, ed. and trans. Greenway, pp. 136-37. For discussion of this theme in Geoffrey's VM, see Barry Lewis's chapter in this volume.

$74 D G B$, i.21.456-59: "Peragratis ergo quibusque prouinciis, repertos gigantes ad cauernas montium fugant, patriam donante duce sorciuntur, agros incipiunt colere, domos aedificare, ita ut in breui tempore terram ab aeuo inhabitatem censeres", "After exploring its various territories and driving off to mountain caves any giants they came upon, they portioned out the land, at their leader's invitation, and began to till the fields and build homes so that, in a short time, the country appeared to have been occupied for many years." For further discussion of the giants and the rhetoric of conquest and colonization, see Coral Lumbley and Michael Faletra's chapters in this volume.

75 Stein, Reality Fictions, p. 112 notes that Arthur's territorial holdings are roughly equivalent to what was controlled by the Anglo-Norman elite in the early 12th century if one includes Cnut's overseas lands. For doubt about whether Geoffrey's Arthur would have recognizably served Anglo-Norman interests at the time, see Gillingham, "Context and Purposes", pp. 21-23.

$76 \quad D G B$, ix.16o.492-96: "ex Britannico genere tercio nasciturum qui Romanum optinebit imperium. De duobus autem adimpleta sunt ipsius oracula, cum manifestum sit praeclaros ut dixisti principes Beli atque Constantinum imperii Romani gessisse insignia." 
Arthur as an imperial figure. ${ }^{77}$ In the $D G B$, Arthur is not a final, brief stand against the Saxons before they take over, but an extension of a continuous imperial project. Arthur is not satisfied with simply defeating and expelling the Saxons; he conquers Europe and attempts to become the third British king to rule Rome as well. It is not until Arthur dies that a succession of rulers, riven by weakness, sodomy, and love of civil strife, allow the Saxons to take over Loegria. ${ }^{78}$ The remainder of the Britons flee to Cornwall and Wales, and the last king, Cadualadrus, is exiled to Brittany. ${ }^{79}$ For Geoffrey, the "passage of dominion" is a long, drawn-out process, compounding many mistakes and failures to unite, that also explains how the descendants of the Britons ended up in Wales, Cornwall, and Brittany. Geoffrey leaves the subsequent history of the Welsh kings to his contemporary Caradog of Llancarfan and the history of the English kings to William and Henry, refusing the continuity between British and English rule that so interests his contemporaries. ${ }^{80}$ Instead, he looks forward to such time as the British can return with the help of their messianic figure.

Because Geoffrey ends his history in 682 and does not bring it up to the present day, the parallels between earlier conquests and the Norman Conquest are less explicit. He does not see the history of the island as beset by a succession of plagues of conquest as Henry does. The Norman Conquest would have been present in the minds of all three authors (and their patrons) since it was so recent, and their interest in conquest can be read in that light. In the case of the Britons, each author sets up the failure of the Britons in moral terms, as discussed above, and in terms of the desertion of the Britons by all its greatest leaders and men: according to Geoffrey and Henry, the British people are left exposed to attack by the Picts and Scots because the best of the Britons have escaped to Brittany, leaving a power vacuum filled by the disastrous Vortigern; according to William, the disastrous reigns of Maximus and the second

77 For Geoffrey's departure from the standard story of Vortigern, Hengist, and Horsa, see Rebecca Thomas's chapter in this volume. Key differences are as follows: Vortigern does not invite the Saxons to Britain; they arrive on their own and then he makes a deal with them. Influenced by Satan, Vortigern is blinded by love for Hengist's daughter Ronwein, and it is the people of Britain who object to the pagan Saxons' presence in Britain because they recognize that they should not mix with pagans. Instead, they nominate Vortimer as their legitimate king. He is a great king, but he is killed, poisoned by his stepmother, Ronwein. For Geoffrey's portrayal of the Britons' resistance of the pagan Saxons as religious war, see Barry Lewis's chapter in this volume.

$78 \quad D G B, x i .180-87$.

$79 D G B$, xi.186.157-6o. Stein, Reality Fictions, p. 119, n. 18 notices that the Saxons assuming ownership by building houses echoes the language of the Britons' arrival at the beginning of the $D G B$.

$D G B$, xi.208.601-03. 
Constantinus leave Britain exposed to neighboring peoples. Vice, misrule, and lack of leadership account for the shift in power.

Parallels are discernible in Henry's and William's accounts of the Norman Conquest, precipitated by the misrule of Æthelred, which prompts the remaining powerful men of England to look to Duke William for direction. Geoffrey implies that the Germans lose rule of the island as retribution for treason, ${ }^{81}$ while Henry writes, "For the Lord Almighty had planned a double affliction for the English people, which He had decided to exterminate for their compelling crimes, just as the Britons were humbled when their sins accused them."82 Through a combination of Fortuna (which William favors as explanation for events), sin, misrule, divine punishment, and the individual choices of the island's rulers, a practical and providential explanation for conquest can be found, undergirding the Norman Conquest and the continued punishment of the descendants of the Britons.

These three authors are united by several common elements: they sought explanation for present-day conditions, with a focus on the conquests the Insular peoples experienced; they were interested in themes of unity, divine punishment, kingship, piety, and the importance of peaceful rulership; they cultivated the same group of patrons; and they constructed their histories according to the conventions of their genre, including the rhetorical flourishes expected of a good prologue: praise of a noble patron, the humility topos, and gestures toward writing in a humble style. Where Geoffrey and his contemporaries depart is in choice of subject matter and the treatment of sources.

In choosing to write a history of the Britons rather than of the English (reflected in the title, De gestis Britonum), Geoffrey must have recognized the value of the subject for his own career advancement as well as for the understanding of history in his day. Because he was raised in Monmouthshire, knew Brittonic language(s) (for he would not claim to have translated the British

$81 \quad D G B$, Prophetiae 113.69-71: "Vix obtinebit cauernas suas Germanicus draco, quia ultio prodicionis eius superueniet. Vigebit tandem paulisper, sed decimatio Neustriae nocebit”, "The German dragon will be hard put to keep possession of its caves, since retribution will be visited on its treason. Then it will prosper for a time, but Normandy's tithe will injure it."

82 Henry of Huntingdon, History of the English vi.1, ed. and trans. Greenway, pp. 338-39: "Genti enim Anglorum, quam sceleribus suis exigentibus disterminare proposuerat, sicut et ipsi Britones peccatis accusantibus humiliauerant, Dominus omnipotens dupplicem contricionem proposuit et quasi militares insidias adhibuit." 
book for his contemporaries had it not seemed credible to them) and was able to find written Welsh and probably Breton sources on the topic, the British past was something he could tackle. ${ }^{83}$ The "gap" he observes in his prologue is therefore not just a trope, but a real gap he identified, recognized, and knew he could best occupy among his contemporaries. ${ }^{84}$ To Geoffrey, the British past was something that he could use to communicate universal truth, to instruct, and to fill a gap in the historical record. He found history to be a suitable form through which to communicate these truths, the gesta, "deeds", of the Britons, which would provide instruction about royal virtue and the dangers of civil war and treachery for the rulers of his own time. This does not necessarily mean he was "pro-Norman" or sought an agenda of Welsh colonization, but that he was using the expertise he had to offer to gain patronage and favor and, through the didactic lessons offered in the $D G B$, to help clean up the mess being wrought by the civil war.

The close attention to written sources and eyewitness testimony is a convention of history writing that Geoffrey deliberately elides throughout the work. Rather than referencing sources throughout his narrative, he references two sources directly, Merlin's prophecies and Walter's ancient book, in what may be a classicizing trope and/or an echo of the Prologue to Dares Phrygius's The Fall of Troy (as well as others in the form of allusion and indirect quotation). ${ }^{85}$ Without extensive references to his sources, his work has not made sense as serious history to modern historians. Instead, it shows a different kind of learning that is just as perceptive and current. The wide reception of the $D G B$ shows that the conventions of eyewitness testimony, evidence gathering, and discernment, while helpful for establishing a work's authority, were not necessary for the success of a historical work in the medieval period. Geoffrey may have sacrificed authority in the eyes of some critics, but he was rewarded richly for providing a compelling, entertaining narrative that filled a much-lamented gap: a reception history that communicated his ideas to a wider audience than he could have imagined.

83 See T.D. Crawford, "On the Linguistic Competence of Geoffrey of Monmouth", Medium Evum $5^{1}$ (1982), 152-62.

84 This is not to minimize the very real political implications of much of the material he offers in the $D G B$, some of which seems quite pro-Norman, though not uncritical of Stephen and Matilda, while elsewhere particularly pro-Breton. Breton and Norman concerns would not in fact have been incompatible at the time, given that Breton nobles were part of the Anglo-Norman ruling class of the day, their ancestors having helped William the Conqueror gain England.

85 See Paul Russell's chapter and the Introduction to this volume for discussion of these points. 